УДК: 330.131 .3

Свпак Юлія, аспірант,

Східноєвропейський національний університет імені Лесі Українки, кафедра аналітичної економіки та природокористування, м. Луцьк; e-mail: 6592479@gmail.com

https://doi.org/10.29038/2411-4014-2019-03-15-22

\title{
ТЕОРЕТИЧНІ ПІДХОДИ ДО КАТЕГОРІЇ «КУЛЬТУРНІ ТА КРЕАТИВНІ ІНДУСТРІЇ»
}

В статті розкрито основні підходи науковців, політиків та практиків до категорії «культурні та креативні індустрії», 3'ясовано стан розробки цього терміну у вітчизняній та зарубіжних літературних джерелах, показано генезис становлення креативної індустрії, як невід'ємної складової трансформації індустріальної системи в їі постіндустріальний тип, запропоновано методологічний інструментарій дослідження зазначеної проблеми, як симбіоз теоретичних, аналітичних та емпіричних елементів, визначено основні риси існуючих моделей креативної економіки, досліджено креативне середовище передових країн світу, класифіковано основні види культурних та креативних індустрій, виділено ряд існуючих концепцій щодо впливу креативного підприємництва на соціально-економічне зростання нації та регіону, запропоновано шляхи та важелі системного впровадження креативного підходу, який грунтується на креативно мислячому людському ресурсі, інноваціях, культурній спадщині та фінансуванні.

Ключові слова: культурні індустрії, креативні індустрії, інновації, підприємництво, попит, євроінтеграційні процеси.

Евпак Юлия, аспирант,

Восточноевропейский национальный университет имени Леси Украинки, кафедра аналитической экономики и природопользования, г. Луцк

\section{ТЕОРЕТИЧЕСКИЕ ПОДХОДЫ К КАТЕГОРИИ «КУЛЬТУРНЫЕ И ТВОРЧЕСКИЕ ИНДУСТРИИ»}

В статье раскрыты основные подходы ученых, политиков и практиков к категории «культурные и творческие индустрии», показано состояние развития этого термина в национальных и зарубежных литературных источниках, прояснен генезис формирования креативной индустрии. В качестве неотъемлемого компонента трансформации промышленной системы в ее постиндустриальном виде предложены методологические инструменты для изучения проблемы, как симбиоз теоретических, аналитических и эмпирических элементов. Определены основные особенности существующих моделей креативной экономики. Исследована креативная среда передовых стран мира, классифицированы основные виды культурных и творческих индустрий, определено ряд существующих концепций влияния творческого предпринимательства. Предложено пути социально-экономического роста нации и региона, пути и рычаги систематического внедрения творческого подхода, основанного на творческом мышлении человеческого ресурса, инноваций, культурного наследия и финансирования.

Ключевые слова: культурные индустрии, креативные индустрии, инновации, предпринимательство, спрос, процессы европейской интеграции.

Yevpak Julia,

PhD student,

Lesya Ukrainka Eastern European National University, Chair of Analytical Economics and Natural Resources Management, Luck

\section{THEORETICAL APPROACHES TO THE CATEGORY «CULTURAL AND CREATIVE INDUSTRIES»}

In the article revealed the main approaches of scientists, politicians and practitioners to the "cultural and creative industries" category, the state of development of this term in national and foreign literary sources is shown, the genesis 
of creative industry formation has been demonstrated. As the integral component of the transformation of the industrial system in its postindustrial type proposed methodological tools for the study of the problem, as a symbiosis of theoretical, analytical and empirical elements, identified the main Features of the existing models of creative economy, investigated the creative environment of the advanced countries of the world, classified the main types of cultural and creative industries, selected a number of existing concepts on the impact of creative entrepreneurship on Socioeconomic growth of the nation and region, the ways and levers of systematic implementation of a creative approach based on creative thinking human resource, innovation, cultural heritage and financing are suggested. Based on critical thinking, available content, assignments, tasks, directions, methods and tools to uncover a dualistic essence and meaning of the concept of "cultural and creative industries" as a business environment and an object of state economic regulation, as well as to analyze the potential of cultural and creative industries in Ukraine. The goal stipulated the need to solve such problems: to describe the state of development of scientific and practical approaches to the functioning of cultural and creative industries; Indicate the instruments for implementing the creative development strategy; To analyze the experience of European countries on development of creative industry; To analyze and develop perspectives of development of cultural industries in conditions of socio-economic growth of region. A methodological base of the study is the combination of theoretical, applied aspects of the role and significance of creative and cultural industries in the economic and social development of the western region. As well as the system of complementary general scientific, theoretical and experimental methods, in particular: empirical (observation, comparison, generalization), theoretical (dialectical, argumentation), methods used for empirical and Theoretical levels of research (analysis, synthesis, induction, deduction) and others.

Key words: Cultural industries, creative industries, innovations, entrepreneurship, demand, European integration processes.

Постановка наукової проблеми. Населенню України притаманний високий рівень креативного потенціалу, який може стати одним 3 найважливіших чинників стабілізації економічної, а також суспільно-політичної ситуації. Творчий потенціал українців має бути спрямований як на забезпечення ефективності традиційних видів економічної діяльності, так і на розвиток креативного сектора економіки, а для цього слід сформувати умови як на державному, так і на регіональному рівнях. Актуальність обраного напряму обумовлена необхідністю оцінки та прогнозу становлення та розвитку креативної економіки в Україні в умовах євроінтеграційних процесів. На сьогодні, такий сектор економіки, як креативний є малодослідженим, тому особливості його протікання в Україні та Західному регіоні в контексті імплементації євроінтеграційних процесів отримують особливого забарвлення.

Аналіз досліджень цієї проблеми. Теоретичні, практичні та методологічні сторони аналізу різних проявів та передумов культурних та креативних індустрій досліджувалися такими науковцями, як: Л. Антошкіною, Є. Зеленцовою, М. Хоркхаймером, Т. Адорно. Зясуванню особливостей та специфіки креативних індустрій присвячені праці Д. Тросбі, Дж. О’Коннор, Дж. Хартлі, Н. Гладких, І. Мацевіч. Як основу креативної економіки розглядають креативні індустрії такі науковці як Дж. Хокінс, Е. Пратт, Р. Флоріда, Т. Флемінг. Визначенню практичної ролі креативних індустрій та їх впливу на підвищення соціально-економічного становища регіонів присвячували свої праці Ч. Лендрі, П. Лінднер, А. Скотт, П. Холл .Проте, не дивлячись на глибину наукових розробок, змістовного наповнення та аналізу культурних та креативних індустрій, варто підтвердити, що їм не вистачає повноти, системності та структурованості. На мою думку, деякі напрями наукового дослідження потребують принципових дискусійних полемік та більш ширшого використання.

Мета та завдання дослідження: базуючись на критичному мисленні, наявних пропозицій змісту, призначення, завдань, напрямів, методів та інструментів розкрити дуалістичну суть та значення поняття «культурні та креативні індустрії», як середовища підприємницької діяльності та об’єкта державного економічного регулювання, а також здійснити аналіз потенціалу культурних та креативних індустрій в Україні. Поставлена мета обумовила необхідність вирішення таких завдань: охарактеризувати стан розробки наукових та практичних підходів до функціонуння культурних та креативних індустрій; вказати на інструменти реалізації стратегії розвитку креативних індустрій; здійснити аналіз досвіду європейських країн щодо розвитку креатичної індустрії; проаналізувати та розробити перспективи розвитку культурних індустрій в умовах соціально-економічного росту регіону. 
Методологічною базою дослідження виступає сукупність теоретичних, прикладних аспектів ролі та значення креативних та культурних індустрій в економічно-суспільному розвитку Західного регіону.

А також система взаємодоповнюючих загальнонаукових, теоретичних , експериментальних методів, зокрема: емпіричні (спостереження, порівняння, узагальнення), теоретичні (діалектичний, аргументації), методи, що застосовують на емпіричному і теоретичному рівнях дослідження (аналізу, синтезу, індукції, дедукції) та інші.

Виклад основного матеріалу й обгрунтування отриманих результатів дослідження. Починаючи 3 другої половини $\mathrm{XX}$ ст. у розвинутих країнах світу розпочався перехід від індустріального до постіндустріального технологічного способу виробництва. Однією із ознак подібної трансформації стало переміщення більшості індустріальних підприємств із країн Західної Європи до країн з більш дешевою робочою силою, оптимальними кліматичними та економічними умовами. Серед наслідків подібних змін можна вважати зміну структури робочої сили та зайнятості, що проявилася у переорієнтації на сферу послуг; зміна структури витрат та специфіки споживання. Сьогодні собівартість продукції становить $20 \%$ ціни, тоді як $80 \%$ - це витрати на маркетинг.

Одним із інструментів подолання соціально-економічних викривлень, що були спричинені зазначеними тенденціями, став розвиток креативної економіки, в основі якої було покладено креативні індустрії. Основними іiі елементами стають інформація, креативний клас, авторські розробки та інтелектуальне право власності. Питання визначення сутності креативний індустрій нині, у контексті підписання Україною угоди про долучення до програми «Креативна Європа», стало не просто актуальним, а навіть гарячим.

Тривалий час інноваційні сфери економіки залишалися без достатньої уваги, проте нині є очевидним, що існуючий екстенсивний спосіб ведення господарської діяльності вичерпав себе та в подальшому призведе до катастрофічних наслідків. Інновації мають стати пріоритетним напрямом розвитку національного господарства та економічної системи, заснованої на знаннях та інформації. Ще донині вчені не прийшли до остаточного спільного визначення креативних індустрій, їхньої структури. Залишається не закритим питання співвідношення креативних, культурних та творчих індустрій. Проте очевидною є зацікавленість світового наукового товариства даною тематикою. Виявлення взаємозв'язків мистецтва, культури та економіки, законів їх взаємодії є перспективним напрямом економічних досліджень.

Серед основних поглядів на зазначену проблему, слід виділити найбільш значущі, зокрема, Антошкіна Л.І. креативні індустрії визначає як «підприємництво у сфері культури», «культурні або творчі бізнеси». У цьому сенсі поняття «індустрії» забезпечує даний сектор економіки смисловим і технологічним змістом, визнаючи його як виробництво і реалізацію певного типу продукції. У сучасній науковій літературі прийнято говорити про створення творчих або культурних продуктів. Науковець стверджує, що креативні індустрії - це новий сектор економіки, зайнятий розробкою нових творчих продуктів, їх виробництвом і реалізацією [3]. Зеленцова Є.В. «креативні індустрії» визначає як тип соціально-культурних практик, домінантою в яких виступає творча, культурна компонента. При цьому автор часто ототожнює поняття «креативні індустрії» та «культурні індустрії». Власне головною проблемою в розумінні сутності креативних індустрій є їх ототожнення 3 індустріями культури. М. Хоркхаймер і Т. Адорно, під терміном «культурні індустрії», розуміли промисловий спосіб комерціалізації розваг (мовлення, кіно, видавничу вправу, музику) та відрізняли його від дотаційного мистецтва у його класичному розумінні (візуальне та виконавське мистецтво, діяльність музеїв і галерей). Лише із запровадженням програм культурної політики в європейських країнах розуміння культурних індустрій виходить за рамки творчості і набуває комерційного змісту. Розвиток цифрових технологій призвів до того, що культурні індустрії стали частиною науковотехнічного прогресу і об’єктом купівлі-продажу, як результат для їх позначення почали використовувати термін «креативні індустрії». Крім того, використання терміну «креативні індустрії» пов'язане також і з тим, що культура перестає бути елітарною та інклюзивною, а також стає ключовим елементом державної культурної політики. Соціологи Дж. Ло та Б. Латура розглядають креативні індустрії як мережу взаємодії різних типів соціальних і фізичних акторів. В основі їх концепції креативних індустрій лежить мережева теорія, що дозволяє визначити роль креативних індустрій у формуванні соціокультурного середовища [5]. 
Уперше поняття індустрії культури було введено у науковий обіг дослідниками Т. Адорно та М. Хогхаймером у книзі «Діалектика Просвітництва» 1947 р. Наприкінці 60-х рр. ХХ ст. посилюється взаємозв'язок між бізнесом та культурою. Такі індустрії як кіно, телебачення, музична індустрія і рекординг все більше набувають соціального та політичного значення. Термін «культурні індустрії» починає вживатися у множині. У 90-ті pp. XX ст відбувається стрімке прискорення комп'ютеризації, поширенням цифрової культури та Інтернету. Усе це призводить до розгляду культурних індустрій як ядра креативної економіки. Отже, ХХ ст. було пов'язано з процесом цифрування культури та мистецтва [1].

Культурні індустрії - це унікальний сектор економіки, який виник внаслідок поширення масової комунікації та глобалізму. У Великобританії сектор культурного підприємництва в 1998 році офіційно був переданий у підпорядкування Департаменту культури, медіа і спорту (DCMS) уряду, що ще раз засвідчує, що ця країна $є$ одним із лідерів та законодавців розвитку креативного підприємництва.

Одне $з$ визначень культурних індустрій стверджує, що це «діяльність, в основі якої лежить індивідуальне творче начало, навик чи талант, і яка може створювати додану вартість і робочі місця шляхом створення та експлуатації інтелектуальної власності» [4].

3 огляду на значний вплив на економіку, програми підтримки розвитку креативного підприємництва займають ключове місце в соціально-економічній політиці міст і країн Європи та Північної Америки і набувають дедалі зростаючого значення в інших регіонах світу.

Креативна економіка - це особливий сектор економіки, до якого зараховують різні ринки в залежності від класифікаційних факторів. Але об'єднує усі ринки одна спільна риса - вони базуються на використанні людських знань і умінь у продукуванні нових і креативних продуктів. Продукти креативної економіки - товари та послуги, поява яких неможлива без активного залучення їх творця. Україна ще на початкових етапах розвитку сектору креативної економіки. Креативна економіка - це особливий сектор економіки, що базується на інтелектуальній діяльності людини, його основними характеристиками є: висока участь нових технологій в різних областях діяльності людини; високий рівень невизначеності; великий обсяг вже існуючих знань і гостра необхідність генерації нових знань. [7]

Поняття «креативна економіка» вперше було введено в обіг журналом Business Week в серпні 2002 року в статті «THE 21ST CENTURY CORPORATION: The Creative Economy». У ній автор розмірковує про те, що чекає корпорації в двадцять першому столітті, як будуть вони адаптуватися до умов нової економіки, де все більше і більше зростає важливість ідей, а основним засобом виробництва стають інтелектуальні ресурси [14].

Креативна економіка не може існувати без креативного суспільства. У розвитку креативного суспільства головну роль відіграють нові ідеї та інновації, а його об'єктами стають такі сфери як: економіка, наука, техніка, політика, соціальна сфера, регіональний розвиток, галузі, підприємства, товари, технології, освіта, культура, мистецтво, спорт та ін. Як показує досвід розвинених країн (США, Японії, Швеції, Німеччини та інших) основними характеристиками креативного суспільства $€$ : наявність креативного класу, тобто люди які займаються інноваційними розробками в різних областях (вчені, інженери, викладачі ВНЗ, архітектори, дизайнери, письменники, журналісти та ін.); систематичне інвестування в інновації в різних сферах (економіка, наука, техніка, соціальна сфера, політика, культура та ін.); зростання практичної віддачі від витрат на інновації; збільшення кількості професіоналів, зайнятих креативної роботою в різних областях; розвиток венчурного капіталу; розвиток інноваційних інфраструктур (технопарки, інноваційно-технологічні центри і комплекси, інноваційні венчурні фірми, бізнес-інкубатори) [8].

Основними факторами зростання креативної економіки є людський потенціал, внутрішній попит, інновації, інвестиції; факторами що забезпечують є ефективний креативний, інвестиційний, виробничий і соціальний менеджмент; додатковим фактором є зовнішній попит.

Ознаками креативної економіки є безперервний інноваційний розвиток, велика роль людського капіталу в інноваційному розвитку країни; інвестиції в нові товари, послуги, технології, в розвиток людського капіталу; велика частка наукомісткої продукції в ВВП; конкуренція на основі інновацій; спеціалізація і кооперація в області інноваційної діяльності господарюючих суб'єктів; створення комплексів виробництв мають міжгалузевий i глобальний характер; висока наукоємність 
виробництва і високий рівень професійної підготовки працівників, захист об'єктів інтелектуальної власності. Культурні індустрії охоплюють такі види діяльності: аудіо-візуальна творчість (фільми, ТБ, радіо, нові медіа, музика); туризм; спорт; книги и преса; спадщина (музеї, бібліотеки, архіви та історичне середовище); перформативні мистецтва (театр, виконавське мистецтво і танок); візуальні мистецтва (галереї, архітектура, дизайн і ремесла).

В свою чергу Дж. Браун виділяє 4 ключових елементи інтелектуальної концепції креативних індустрій:

1. Базуються на творчих, художніх можливостях особистостей;

2. Діють в спілці з менеджерами та технологами;

3. Створюють ринкові продукти;

4. Їх економічна цінність має культурне чи інтелектуальне походження;

В центрі уваги сучасного виробництва має бути творчість і тому акцент переноситься 3 промислового сектора на індивідуальну креативність і свободу.

Нові сфери культури, такі як мода, телебачення, дизайн $\epsilon$ переважно комерційними і сприяють появі креативних професіоналів та менеджерів у сфері культури. Для сектору культурних індустрій особливого значення набуває історична, етнічна, соціальна специфіка місця, де сконцентровані творчі сили, що активно впливає на розробку стратегії в галузі культурних проектів.

Оскільки виробництво у сфері культури базується на інформації, то надзвичайний розвиток цифрових технологій і глобалізація мереж обміну інформацією зробили культурний сектор одним із самих динамічних у світі[7].

3 моменту появи розуміння креативної економіки, як окремого сектору економіки було розроблено окремі моделі класифікації культурних та креативних індустрій, проте найбільш затребуваною сьогодні $\epsilon$ модель, розроблена UNCTAD, в якій виділяють чотири групи та дев'ять підгруп креативних індустрій: 1. Культурна спадщина: традиційна культура (ремесла, фестивалі тощо); культурні пам'ятки (музеї, бібліотеки, місця розкопок тощо); 2. Мистецтво: образотворче мистецтво (скульптура, фотографія тощо); виконавче мистецтво (вокал, драматичне мистецтво тощо). 3. Медіа: публікації та видавництво; аудіовізуальні твори (фільми, телебачення, радіомовлення); нові медіа (цифровий контент, відеоігри тощо). 4. Функціональний креатив: дизайн (архітектура, іграшки, ювелірні вироби); креативні послуги (реклама, цифрові й культурні послуги)[5].

У світовій економічній літературі висвітлено декілька моделей, що визначають структуру креативних індустрій та ті сфери діяльності, що відносяться до креативних. Кожна з представлених моделей показує основну мету та методи управління розвитком креативних індустрій. Однак, кожна 3 них як основу креативних індустрій ставить різні види виробництва, різні промисловості, що безперечно значно ускладнює уніфікацію визначення сутності креативних індустрій. Модель креативних індустрій розроблена Департаментом медіа, культури та спорту Великобританії визначає основним інструментом розвитку британської економіки, орієнтованої на світові ринки, креативність та інновації.

Згідно з розробленою моделлю, до креативних індустрій відносяться 13 видів діяльності, а саме: реклама, архітектура, мистецтво та ринок антикваріату, народні ремесла, дизайн, мода, кіноіндустрія, музика, виконавське мистецтво, живопис, програмне забезпечення, телерадіомовлення, відео та комп'ютерні ігри. Однак, уряд країни для позначення обраних галузей використовує термін «культурні індустрії», оскільки він охоплює ширше коло сфер діяльності. Функціональна модель типова для визначення креативних індустрій, заснованих на традиційних видах діяльності, що характерні для країн Європи та Великобританії. Така модель виділяє «високе мистецтво» як основу суспільно-політичного устрою та концентрує увагу на «популярній» культурі. За цим підходом культура у суспільстві формується у процесі виробництва, поширення та споживання через систему функціональних повідомлень, доведених до суспільства засобами масової інформації. Таким чином, виділено 12 креативних індустрій, об'єднаних у 3 функціональні блоки: основні креативні індустрії (реклама, кіноіндустрія, Інтернет, музика, видавнича справа, телерадіомовлення, відео та комп'ютерні ігри), периферійні креативні індустрії (креативне мистецтво), граничні креативні індустрії (мода, спорт, програмне забезпечення, побутова електроніка) [8]. 
Модель концентричних кіл грунтується на припущенні, що вартість креативних товарів та послуг надає їх виробництвам особливих характеристик. Чим більше висвітлений творчий зміст у тому чи іншому креативному товарі, тим більші його можливості на включення до складу креативних. Згідно з положеннями моделі, центром креативних ідей виступають мистецтво, музика, художні промисли, які в свою чергу впливають на інші сфери креативної економіки, що у вигляді кіл розташовані далі від центру. Перше коло обмежує відносні кордони культурних індустрій, які продукують мистецькі товари, захищені авторським правом. Друге коло - креативні індустрії включає виробництво і споживання не тільки культурних товарів, а й креативну продукцію постіндустріальної епохи [6].

Таким чином, дана модель розмежовує товари та послуги за характером їх виробництва, типом виробничого процесу, а також за типом засобів, що використовувались для виробництва таких товарів. Однак недоліком такої моделі $\epsilon$ те, що вона не виділяє чіткої межі між креативними індустріями та іншими секторами економіки. Модель Всесвітньої організації інтелектуальної власності в центрі креативних індустрій ставить сфери діяльності результатом яких $є$ товари, захищені авторським правом. Основою моделі креативних індустрій, побудованої за цією методикою, виступає інтелектуальна власність як головна умова створення креативних товарів та послуг.

Креативні індустрії, згідно визначення ВОІВ, включають ті галузі, в яких вироблений товар або послуга містить істотну частину творчості. Таким чином, виділено 3 функціональні блоки: креативні індустрії, що базуються на інтелектуальній власності (реклама, колекціонування, кіноіндустрія, музика, виконавське мистецтво, видавнича справа, програмне забезпечення, телерадіомовлення, візуальне та графічне мистецтво), суміжні індустрії (цифрові технологій, музичні інструменти, публікації, мистецтво фотографії) та індустрії, що частково охороняються авторським правом (архітектура, легка промисловість, проектування, мода, побутові товари, іграшки, архітектура) .

Основою моделі креативних індустрій, розробленою інститутом статистики ЮНЕСКО, виступають товари та послуги, що безпосередньо беруть участь у міжнародній торгівлі. До складу креативних індустрій за цим підходом належать 13 сфер діяльності, частка яких у міжнародній торгівлі розвинених країн найбільша. Модель виділяє основні креативні товари та послуги (аудіовізуальне мистецтво, книги, товари авторського права, культурна спадщина, періодичні видання, записи, відеоігри, візуальне мистецтво) та пов'язані креативні товари та послуги (реклама, архітектура, аудіовізуальне обладнання, інформаційні послуги, музичні інструменти) [2].

Головною умовою включення галузей до креативних індустрій, згідно моделі Конгресу США, $є$ ïх здатність виробляти та поширювати мистецтво, така модель побудована на так званих «arts-centric businesses». Вона включає до складу креативних індустрій виключно ті підприємства, які безпосередньо пов'язані з виробництвом і розподілом мистецтва, як основного товару. До таких креативних індустрій відносять музеї, театри, сферу архітектури, реклами тощо [5].

Принциповою відмінністю цієї моделі $є$ те, що вона зосереджена виключно на творчих видах діяльності і абсолютно виключає з креативних індустрій такі сфери як комп'ютерне програмування чи наукові дослідження, які за своєю природою, не орієнтовані на мистецтво. Раніше розроблені та впроваджені на практиці моделі Департаменту Медіа, культури та спорту Великобританії, Всесвітньої організації інтелектуальної власності, модель Інституту статистики ЮНЕСКО систематизовано ЮНКТАД (Конференція ООН з торг. та розвитку).

Так, креативні індустрій розглядаються як цикли створення, виробництва та розподілу товарів і послуг, які використовують творчість та інтелектуальний капітал як основний матеріал; креативні індустрії являють собою комплекс заходів, заснованих та орієнтованих на знаннях та мистецтві, але які не обмежені ними та несуть в собі потенційні можливості отримання доходів від торгівлі креативними товарами і послугами та реалізації прав інтелектуальної власності; індустрії, що орієнтовані на виробництво матеріальних продуктів та нематеріальних інтелектуальних чи мистецьких послуг, наділених творчим змістом, економічною цінністю та ринковими цілями; креативні індустрії представлені як новий динамічний сектор світової торгівлі, що знаходяться в тісній взаємодії із мистецтвом, культурою та промисловістю.

Таке розуміння креативних індустрій дає змогу виділити чотири сектори: мистецтво (архітектура, фотографія, антикваріат, музичне мистецтво, театр, циркове мистецтво тощо), 
спадщина (музеї, бібліотеки, виставки, фестивалі, традиційне мистецтво тощо), медіа (видавнича справа, ЗМІ, телерадіомовлення тощо), функціональні індустрії (дизайн, мода, реклама, цифровий контент).

У країнах СС культуру та креативність вважають дуже перспективною, оскільки на ії теренах функціонує другий за величиною ринок креативної економіки, який поступається лише ринку Азіатсько-Тихоокеанського регіону. Дохід від функціонування креативних індустрій європейських країн перевищує 700 млрд. дол. США, що становить $32 \%$ від світових доходів креативного сектору. Відтак, з боку головних органів $Є С$ та національних урядів останнім часом спостерігається велика зацікавленість у розвитку креативних і культурних індустрій [1].

На креативну економіку в ЄС спрямована значна державна підтримка, яка проявляється через закупівельну активність, реалізацію фінансових та податкових пільг, субсидіювання та сприяння зайнятості населення в даному секторі. Так, у 2013 році, уряди країн $Є С$ виділили майже 68,6 млрд. дол. США на культурні послуги [2].

Важливість інвестицій у креативні і культурні індустрії підкреслює рамковий документ програма Європейської Комісії «Креативна Європа», розрахований на 2014-2020 рр. Програма спрямована на підтримку європейського кіно, культури та креативного сектору, що надає їм можливість збільшити контрибуцію у зайнятість населення та економічне зростання. Досвід розвинених країн світу (Великобританії, Канади, США, Японії) вказує, що в контексті розвитку Західного регіону креативних індустрій важливим $є$ пошук альтернативних форм фінансування, зокрема через систему державно-приватного партнерства. Така форма фінансування креативних індустрій позитивно впливає на загальну конкурентоспроможність територіальних суспільних систем за рахунок залучення інвестицій регіонами, спрямованих на розвиток людського та інтелектуального капіталу (системи професійної підготовки та перепідготовки кадрів, розробки та впровадження нових технологій) та розбудову інфраструктурного забезпечення розвитку креативних індустрій (формування гармонійної, адаптивної, системи креативних індустрій, організацій i інституцій, що забезпечуватимуть ефективну взаємодію представників креативного класу, створення належних умов для їх роботи та відпочинку).

Світова практика показує досить позитивний досвід залучення кредитних коштів для фінансування креативних індустрій в Західному регіоні. Однак стан ринку кредитування в Україні, під впливом зовнішніх та внутрішніх чинників, спровокованих затяжною фінансовою кризою, нестабільністю суспільно-політичної ситуації не дозволяє в повній мірі задовольнити потреби креативного сектору у кредитних коштах. Це пов'язано з тим, що загальні негативні тенденції розвитку кредитного ринку призвели до зростання вартості кредитних коштів та посилення кредитних ризиків. Вагомим недоліком кредитування як форми фінансування креативних індустрій в Західному регіоні $є$ невідповідність рентабельності діяльності суб'єктів креативного підприємництва розміру відсоткових ставок, що формують вартість кредитів. До того ж специфіка кредитування вимагає ліквідної застави від суб'єктів кредитування.

Висновки та перспективи подальших досліджень. Креативна економіка змінить традиційні моделі економічного зростання, джерела отримання доданої вартості, розуміння факторів розміщення бізнесу. Вона висуває нові вимоги до робочої сили, виробничої інфраструктури та інституційного оточення порівняно з індустріальною економікою. Цей сектор перетворюється на важливий стратегічний інструмент ревіталізації та трансформації регіонів.

Основою підприємницької діяльності в креативному секторі $\epsilon$ підприємства малого та середнього бізнесу. Розвиток та підтримка підприємницької ініціативи в креативному секторі $\epsilon$ ефективним та іміджевим інструментом залучення інвестицій до країни.

\section{Джерела та література}

1. Антошкіна Л.I. Креативні індустрії: проблеми i перспективи розвитку. URL: http://ir.kneu.kiev.ua:8080/bitstream/2010/1783/1. (дата звернення: 10.08.2019).

2. Брикова I. В. Роль креативних регіонів у підвищенні міжнародної конкурентоспроможності країн в умовах глобалізації. Міжнародна економічна політика: науковий журнал. КНЕУ, 2011. Вип. №1-2(1415). - C. $211-245$. 
3. Журавлев В. А. Креативное общество, креативная єкономика и инновации URL: https://bgscience.ru/lib/10787. (дата звернення: 10.08.2019).

4. Лошковська X. С. Креативні індустрії як сучасний сегмент стратегічного розвитку країн світу. URL: http://meim.kneu.edu.ua. (дата звернення: 10.08.2019).

5. Мацевич И.Я. Креативное общество: в поисках релевантной социальной теории Социология: теория, методы, маркетинг. 2010. №2. С. 98-111.

6. Хезмондалш Д. Культурные индустрии. Пер. с англ. И. Кушнаревой, под ред. А. Михалевой. Нац. исслед. ун-т «Высшая икола экономики». 2014. 456 с.

7. Чуль О.М. Моделі креативних індустрій:короткий огляд. Збір. тез наук. робіт учасників Міжнародної науковопрактичній конферениії «Сучасна економічна наука: теорія і практика». 26-27 жовтня. Одеса, 2012. C. 13-15.

8. Чуль О.М. Система креативних індустрій як основа формування креативної економіки в регіоні. 36. наук. пр. «Економічні науки». Серія: «Облік та фінанси». Випуск 10 (37). Ч.5. Луцьк: ЛНТУ, 2013. C.166-173.

\section{References}

1. Antoshkina L.I. Kreatyvni industrii: problemy i perspektyvy rozvytku [Creative Industries: Challenges and Prospects for Development]. Retrieved from http://ir.kneu.kiev.ua:8080/bitstream/2010/1783/1. [in Ukrainian].

2. Brykova I. V. (2011). Rol kreatyvnykh rehioniv u pidvyshchenni mizhnarodnoi konkurentospromozhnosti krain $v$ umovakh hlobalizatsii [The role of creative regions in enhancing international competitiveness of countries in the context of globalization]. Mizhnarodna ekonomichna polityka: nauk. zhurn. - International Economic Policy: Sciences. D. Lukianenko (Ed.)., 1-2(14-15), (pp. 211-245). Kyiv: DVNZ «Kyiv. nats. ekon. un-t im. Vadyma Hetmana» [in Ukrainian].

3. Zhuravlev V.A. Kreatyvnoe obshchestvo, kreatyvnaia yekonomyka y ynnovatsyy [Creative Society, Creative Economy and Innovation]. Retrieved from https://bgscience.ru/lib/10787 [in Russian].

4. Loshkovska Kh. S. Kreatyvni industrii yak suchasnyi sehment stratehichnoho rozvytku krain svitu [Creative industries as a modern segment of strategic development of the countries of the world]. Retrieved from http://meim.kneu.edu.ua [in Ukrainian].

5. Matsevych Y.Ia. (2010). Kreatyvnoe obshchestvo: v poyskakh relevantnoi sotsyalnoi teoryy [Creative Society: Searching for Relevant Social Theory]. Sotsyolohyia: teoryia, metodu, marketynh. - Sociology: theory, methods, marketing, 2, 98-111 [in Russian].

6. Khezmondalsh D. (2014). Kulturnie yndustryy [Cultural industries] (A. Mykhaleva \& Y. Kushnarova, Trans). Moscow: nat. researched University "Higher School of Economics" [in Russian].

7. Chul O.M. (2012). Modeli kreatyvnykh industrii:korotkyi ohliad [Creative Industries Models: A Brief Overview]. Z Zb. tez Nauk. Prats. Mizhnarodna naukovo-praktychna konferentsiia «Modern Economic Science: Theory and Practice». (accessed 26-27 October 2012), (pp. 13-15). Odessa. [in Ukrainian].

8. Chul O.M. (2013). Systema kreatyvnykh industrii yak osnova formuvannia kreatyvnoi ekonomiky v rehioni [The system of creative industries as a basis for the formation of creative economy in the region]. Zb. nauk. pr. «Ekonomichni nauky». Seriia: "Oblik ta finansy». - Coll. Sciences. Economic Sciences. Series: Accounting and Finance. Collected papers (10 (37), Vols. 5), (pp. 166-173). Lutsk: LNTU [in Ukrainian].

Стаття надійшла до редакції 08.08.2019 р. 